\title{
ERECTILE DYSFUNCTION IN WORKERS CHRONICALLY- EXPOSED TO PESTICIDES AND ORGANIC SOLVENTS IN DAMIETTA GOVERNORATE
}

\author{
$B Y$ \\ Soliman Shreed Soliman; Abdel-Shafy Awad Allah*; \\ Zakaria Mahran Ebied** \\ Departments of Forensic Medicine and Clinical Toxicology, Radiology*, \\ **Dematology and Andrology. Al-Azhar Faculty of Medicine, Damietta
}

\section{ABSTRACT}

Erectile dysfunction is defined as the persistent inability to achieve or to maintain an adequate erection for satisfactory sexual performance. The causes of impotence can be classified as due to neurological, psychological, endocrinological, local structural diseases or toxic substances. This is the first clinical study to assess ED in patients chronically exposed to pesticides and toxic chemical solvents in Damietta governorate. During the period from April 2006 to April 2008, 87 patients were examined, who fulfill the inclusion criteria and agreed to complete the study; they were subdivided into two groups; the first group included those exposed to pesticides, and the other group included patients exposed to toxic solvents. All patients were subjected to history taking, general examination, laboratory investigations "liver and kidney functions; total serum testosterone" and penile duplex examination. In conclusion, it Ias been revealed that ED in chronic pesticides and toxic solvents exposures is largely a result of impaired penile veno-occlusive mechanism and more than one factor or mechanism is associated with ED due to exposure to both pesticides and solvents.

\section{INTRODUCTION}

Erectile dysfunction (ED) is a common problem with significant effects on the quality of life of aging males worldwide. Some epidemiologic studies reported elevated risk among farm workers and pesticide applicators. Duplex study played an important role in diagnosing ED as non invasive tool and it was excellent achieving the task indicating whether a vasculogenic "arterial or venous lesion" or non vasculogenic cause is defined.

Erectile dysfunction is defined as the persistent inability to achieve or to maintain an adequate erection for satisfactory sexual performance (NIH, 1993).

A community-based study carried out in the USA indicated that ED affects $50 \%$ 
of males older than 45 years with $10 \%$ suffering complete ED (Feldman et al, 1994). Reports from different parts of the world indicate great variation of prevalence of ED ranging between 5.4 and $82.2 \%$. These studies point out various risk factors that are associated with ED. The most important risk factors are hypertension, diabetes, heart disease, hyperlipidemia, smoking, drug use and endocrinopathies (Dunn et al., 1996; Ventegodt, 1998; Moreira et al., 2001).

Medical disorders that impair blood flow, neuronal pathways, endocrine regulations, psychological factors and relationship problems may cause erectile dysfunction. The causes of impotence can be classified as due to neurological, psychological, endocrinological, local structural diseases or toxic substances (Morgentaler, 1999).

Indirect evidence of a pctential effect of environmental contaminants of industrial and agricultural origin with suspected endocrine disrupting properties on ED risk comes from animal studies (Brien et al., 2000) and some epidemiologic studies reporting elevated risk among farm workers and pesticide applicators (Espir et al., 1970; Amr et al., 1997; Oliva et al., 2002).

There has been intense scientific and societal concern regarding the potential adverse effects of environmental endocrine disrupters on male reproductive function and development (Toppari et al., 2002; Wetherill et al., 2005). However, very little attention has been paid to the effect of such agents on erectile function as a critical component of male reproductive function (Polsky et al., 2007).

Ubiquitous environmental pollutants, such as polychlorinated biphenyls (PCBs) and chlorinated pesticides, with known or suspected endocrine-disrupting properties may modulate the normal functioning of endogenous hormones as agonists, as antagonists, or as mixed agonist-antagonist activity, particularly with respect to estrogen or testosterone activities (Toppari et al., 1996; Wolff et al., 1997).

DDT has been one of the most widely used chemicals for insects control (Moysich et al., 2002). Although banned from use and manufacture in the United States and Canada nearly 30 years ago (Longnecker et al., 1997), these chemicals persist in the environment, accumulating in the food chain. As a result, organochlorines are now detectable in most human plasma, adipose tissue, and breast milk (Charlier and Plomteux, 2002).

In Western countries, major sources of organochlorine contaminants include foods, particularly meat, fish, and dairy products, as well as water, soil, and dust (Paris-Pombo et al., 2003). 
In recent decades, several reports have implicated exposure to pervasive estrogenic or antiandrogenic environmental contaminants in adverse effects on male reproductive function and development, such as a worldwide decline in sperm counts (Sharpe and Skakkebaek, 1993; Swan et al., 2000) and increased rates of male reproductive tract abnormalities (Vrijheid et al., 2003) and testicular cancer (Adami et al., 1994).

The male erection is controlled by a complex interplay between neural, vascular, and hormonal factors (Mills et al., 1996). It is plausible that organochlorine pesticides and various industrial chemicals with documented antiandrogenic or estrogenic properties (eg, DDT and its metabolites, PCBs) can interfere directly or indirectly with the action of sex hormones, such as androgens, thus negatively impacting erectile function (Polsky et al., 2007).

Thus, the present study was designed to investigate the possible relation between chronic pesticides and organic solvents exposure and erectile dysfunction.

\section{PATIENTS AND METHODS}

The present work was carried out in the period from April, 1st, 2006 to April, 1 st, 2008, and patients were selected from those attending Al-Azhar University Hos- pital (New Damietta) seeking medical advice for impotence the study included initially 187 males reduced to 87 cases fulfilled the inclusion criteria and agreed to complete the study.

The inclusion criteria included: 1) the patient has been married for at least 6 months; 2) reported erectile dysfunction for at least 2 months; 3) non smoker, and has not any other known risk factors for ED as diabetes, hypertension, obesity or on medical therapy with psychotropic drugs; 4) occupational history of exposure to pesticides and other chemical for more than 3 years whether in continuous or intermittent (seasonal) pattern, and 5) had no psychological troubles.

The included 87 cases were subdivided into two subgroups according to exposure substances: subgroup-1, included 47 cases, with occupational exposure to pesticides and they were working in the field of agriculture or Biochemical Industries Company; and subgroup-2, included those with continuous exposure to solvents (working in the field of furniture industry: mixed types of solvents according to the field at which the worker doing his work).

History taking: the personal history and socio-demographic data were assessed. Then sexual history was reviewed. The essential components of sexual func-

Vol. XVI, No. 2, July 2008 
tion assessment included: erectile insufficiency (onset, duration, progression, severity of the problem, qualification of $\mathrm{ED}$ as it relates to sex with a partner, nocturnal/morning erections, self-stimulatory, and visual erotic-induced erections), altered sexual desire, ejaculation, orgasm, sexually related genital pain disorders, and partner sexual function.

General examinations included measurement of body weight, height, and calculation of body mass index (BMI), any patient with $\mathrm{BMI} \geq 29.9 \mathrm{~kg} / \mathrm{m}^{2}$ was excluded. Measurement of hemodynamic parameters as pulse, blood pressure, and any hypertensive cases were excluded. Liver and kidney functions were assessed through laboratory investigation and again cases with abnormal findings were excluded from the study.

Laboratory and radiological investigations included estimation of serum testosterone levels and assessment of different penile duplex parameters.

Serum total testosterone (TT) was measured in the morning (normal range 280-800 $\mathrm{ng} / \mathrm{dl}$ ) using the electrochemiluminescence immunoassay (ECLIA) used on the Roche Elecsys 1010/2010 Boehringer Manheim GmbH, Germany) (Oliva et al., 2002).

Ultrasound of the corpora was per- formed in all directions to detect any associated penile fibrosis. Cavernosal artery diameters were measured by ultrasound. Following intracavernous injection of $0.5 \mathrm{ml}$ of a trimix solution containing $3.6 \mathrm{mg}$ of prostaglandin E1, $0.4 \mathrm{mg}$ of phentolamine, and $9.6 \mathrm{mg}$ of papaverine (Bennett et al., 1991). Every patient was asked to manually stimulate his penis in a comfortable environment to induce maximal vascular flow. If the erection achieved during the first color duplex ultrasound (CDU) was judged to be inadequate (E0-E3 according to Gerstenberg et al. (1989) classification, a booster injection was used to double the dose in the same setting. In few cases with inadequate response to the vasoactive drug, a second visit was offered to the patient and intracavernosal injection (ICI) of $1 \mathrm{ml}$ of the trimix solution was given. Identification of the cavernous arteries was carried out bilateral$l y$, and measurement of blood flow was performed in their proximal part, using a Doppler cursor angle of 45 degrees. Post-injection and manual-stimulation measurements were obtained at $5,10,20$, and 30 minutes. A peak systolic velocity (PSV) measurement of $\geq 30 \mathrm{~cm} /$ second and an end diastolic velocity (EDV) measurement of $\leq 5 \mathrm{~cm} /$ second were considered normal to exclude vascular disease (Gestenberg et al., 1989). Vasculogenic ED includes the sum of arteriogenic and venogenic $E D$. 


\section{RESULTS}

Patients profiles (tables 1, 2): the mean age in pesticides exposed group was $38.25 \pm 10.51$ years compared to $33.60 \pm 6.37$ years in solvents-exposed group. Exposure time was longer in group II $(11.70 \pm 5.03$ years $)$ in comparison to group I (10.46 \pm 4.21 years). Erectile dysfunction period was longer in pesticides exposed group ( $5.38 \pm 2.82$ months vs $5.15 \pm 2.57$ months in solvents exposed group). Also, there was no significant differences between both groups as regard height, weight, BMI, pulse, systolic and diastolic blood pressure.

Testosterone levels and basic penile duplex parameters were shown in tables $(3,4)$ and figures $(1,2)$ : testosterone levels showed great variability, but still within normal range. There was statistically non significant decrease in its levels in pesticides exposed group in comparison to solvents exposed group $(298.89 \pm 68.78$ vs $309.75 \pm 69.53 \mathrm{ng} / \mathrm{ml}$ respectively).

PSV in group I was $29.02 \pm 10.09 \mathrm{~cm} / \mathrm{sec}$ compared to $27.10 \pm 9.52 \mathrm{~cm} / \mathrm{sec}$ in group II while EDV was $3.18 \pm 3.24 \mathrm{~cm} / \mathrm{sec}$ in group I compared to $3.11 \pm 3.96 \mathrm{~cm} / \mathrm{sec}$ in group II. RI was $0.77 \pm 0.11$ in group I compared to $0.78 \pm 0.13$ in group II. There was statistically non significant differences beween both groups as regard penile duplex parameters except for maintenance flow which was $20.36 \pm 3.83$ in group I compared to $22.05 \pm 3.73$ in group II .

\section{DISCUSSION}

To our knowledge, this is the first clinical study to evaluate ED in pesticides and solvents exposed subjects carried out in Damietta Governorate. The present study was designed to examine the possible relation between exposure to both pesticides and solvents and ED. Thus, other known risk factors for ED were avoided as much as possible. This effort to avoid other risk factors is will known from the large number of cases included in the study at first before exclusion of 100 cases that not meet the inclusion criteria.

All included men in this study were exposed to either pesticides or solvents in their work for a long period. This suggests a relationship between these factors and erectile dysfunction. Exposure prevalence have been increased by the geographic region in which these men live, which is a major industrial and agricultural area.

The average age in solvents exposed group was $33.60 \pm 6.37$ years while it was $38.25 \pm 10.51$ years in pesticides exposed groups and the difference was statistically significant. This implies that solvents exposed group presented with ED nearly 6 years earlier than did pesticides exposed group. The average age reported in the 
study by Oliva et al. (2002) was 48.7 years and this age is higher than that reported in the present study that means that ED presented early in included cases. This interesting observation can be explained by the fact that younger persons are incorporated in farming and furniture works in Damietta governorate.

The present work showed that among men who consulted for erectile disorders, exposure to pesticides or solvents is associated with an increased risk of having an abnormal nocturnal erectile pattern. These results are consistent with previous observations. In 1970, a British study found that a team of 4 farm workers who had been using various pesticides for intensive agriculture became impotent (Espir et al., 1970). No other medical or psychological causes were apparent and they recovered their erectile function after discontinuing use. This suggests that there was a relationship between exposure to pesticides and the occurrence of impotence. Another study found that nearly $27 \%$ of Egyptian pesticide formulators are impotent, compared with $4 \%$ in a control group matched for age (Amr et al., 1997).

Erectile problems have also been reported among viscose-rayon production workers, who are exposed to the solvent carbon disulfide (Vanhoorne et al., 1994). The intensive use of solvents is suspected to be the cause of the increasing number of complaints of impotence among lacquer users in the Danish furniture industry (Sabroe and Olsen, 1979).

The present work revealed decrease in serum testosterone levels (total serum testosterone levels). It must be noted that although decreased, serum testosterone levels remains within the normal range, but it may be blamed for reported ED.

Male erection is basically a vascular event, controlled by a complex interplay between neural and endocrine factors. Some organochlorine pesticides and various industrial chemicals have estrogenic or antiandrogenic endocrine properties and interfere directly or indirectly with fertility and reproduction (Toppari et al., 1996; Cheek and McLachlan, 1998).

In the past, male manufacturing workers who came into contact with the potent synthetic estrogen, diethylstilbestrol, and its industrial derivative, diamino-stilbene, reported impotence and a decrease in libido (Shmunes and Burton, 1981; Quinn et al., 1990). It was shown that the endocrine disrupter, p,p9-DDE, a persistent antiandrogenic metabolite of the insecticide DDT, interferes with erectile function in rats (Brien et al., 2000). This supports the hypothesis that active environmental hormonal substances may cause erectile dysfunction. 
Other pesticides (eg, organophosphorus and carbamates) are recognized as neurotoxicants, and cause variety of problems in the human central nervous system. In the same way, exposure to solvents induces disturbances in the central nervous system and number of claims have been made that common solvents may cause behavioral toxicity (White and Proctor, 1997). In addition, exposure to carbon disulfide has been shown to change serum levels of gonadotropins, suggesting that it acts on the hypothalamic-pituitary-gonadal axis (Lancranjan et al., 1969).

Zohdy et al. (2007) believed that the higher incidence of vasculogenic ED among their obese men is among other factors, due to androgen deficiency that produces a metabolic and structural imbalance in the corpus cavernousm, resulting in venous leakage and ED. It was reported that testosterone replacement therapy may restore erection in men with venous leakage (Yassin et al., 2006).

Christ-Craina et al. (2004) stated that the testosterone values did not correlate with clinical signs and symptoms of hypogonadism and that the symptoms of aging men are multifactorial and should not be indiscriminately assigned to ageassociated decreases in testosterone levels.

The duplex study revealed affection of both groups nearly to the same extent but solvent exposed group showed higher MF values and these results points to the vasculogenic nature of ED reported. Also, there was no difference between both groups as regard changes in the degree of carvenosal artery dialation, PSV, EDV and RI.

Interestingly, the difference in the average PSV between both groups was not statistically significant, whereas the average MF was significantly higher in solvents exposed group. These results signify that MF (indicator of venous involvement) is more impaired by solvents than the PSV (indicator of arterial involvement). This result might be explained by the lower average age in solvent exposed group compared with the pesticides exposed group. It could be speculated that impairment of venous drainage plays a more significant role in younger ED patients because of biochemical alteration and toxicological changes induced by solvents. The environmental agents we studied are more strongly associated with the forms characterized by a flat erectile pattern than with those characterized by an irregular erectile pattern. Whether this corresponds to a different pathogenic mechanism remains to be elucidated. Considerable attention has been focused on the potential effects of a large variety of environmental contaminants of industrial origin on male reproductive function with particular attention 
to testicular cancer, genital malformations, and sperm quality (Oliva et al., 2002).

The results of the present study revealed that ED in pesticides and solvents exposures is largely a result of impaired penile veno-occlusive mechanisms. This finding may serve to guide further studies investigating the biological basis of erectile pathology in exposure of pesticides and environmental substances.

In conclusion, the results of the present study, revealed that more than one factor or mechanism is associated with ED due to exposure to both pesticides and solvents. Thus, we believe that sexual dysfunction deserves further studies because it results from the deleterious effects of environmental chemicals. 
Table (1): Patient profile of studied groups.

\begin{tabular}{|c|c|c|c|c|c|c|}
\hline \multirow{3}{*}{$\begin{array}{ll} & \\
\text { Age (years) } & \\
\end{array}$} & \multirow{2}{*}{\multicolumn{2}{|c|}{$\begin{array}{c}\text { Group I (Pesticides) } \\
\text { Mean } \pm \text { SD } \\
\end{array}$}} & \multirow{2}{*}{\multicolumn{2}{|c|}{$\begin{array}{c}\text { Group } 11 \text { (Solvents) } \\
\text { Mean } \pm \text { SD }\end{array}$}} & \multirow{3}{*}{$\frac{t}{2.44}$} & \multirow{3}{*}{$\frac{p}{0.017^{*}}$} \\
\hline & & & & & & \\
\hline & $38.25 \pm$ & 10.51 & $33.60 \pm$ & 6.37 & & \\
\hline Exposure time (years) & $10.46 \pm$ & 4.21 & $11.70 \pm$ & 5.03 & 1.24 & 0.21 \\
\hline Erectile dysfunction duration (months) & $5.38 \pm$ & 2.82 & $5.15 \pm$ & 2.57 & 0.39 & 0.69 \\
\hline Height (cm) & $174.06 \pm$ & 3.37 & $174.57 \pm$ & 4.56 & 0.60 & 0.55 \\
\hline Weight (kg) & $76.06 \pm$ & 3.37 & $76.66 \pm$ & 4.56 & 0.58 & 0.57 \\
\hline BMI $\left(\mathrm{kg} / \mathrm{m}^{2}\right)$ & $25.09 \pm$ & 0.13 & $25.10 \pm$ & 0.18 & 0.27 & 0.78 \\
\hline
\end{tabular}

Table (2): Pulse and blood pressure in studied groups.

\begin{tabular}{|l|cc|cc|c|c|}
\hline & Group I (Pesticides) & \multicolumn{2}{|c|}{ Group II (Solvents) } & \multirow{t}{*}{$\boldsymbol{t}$} & \multirow{2}{*}{$\mathbf{p}$} \\
\hline & \multicolumn{2}{|c|}{ Mean \pm SD } & \multicolumn{2}{|c|}{ Mean \pm SD } & & \\
\hline Systolic blood pressure & $124.68 \pm$ & 6.71 & $125.25 \pm$ & 5.94 & 1.60 & 0.11 \\
\hline Diastolic blood pressure & $69.68 \pm$ & 5.75 & $70.55 \pm$ & 5.94 & 1.03 & 0.32 \\
\hline Pulse & $74.38 \pm$ & 4.58 & $74.27 \pm$ & 3.67 & 0.12 & 0.91 \\
\hline
\end{tabular}

Table (3): Testosterone levels in studied groups.

\begin{tabular}{|c|cc|c|c|}
\hline & \multicolumn{2}{|c|}{ Testosterone levels (mean \pm SD) } & $t$ & $p$ \\
\hline Group I (Pesticides) & $298.89 \pm$ & 68.78 & \multirow{2}{*}{0.73} & 0.46 \\
\hline Group II (Solvents) & $309.75 \pm$ & 69.53 & & \\
\hline
\end{tabular}

Table (4): Comparison between group I and II as regard radiological assessment.

\begin{tabular}{|c|cc|cc|c|c|}
\hline & \multicolumn{2}{|c|}{ Group I (Pesticides) } & \multicolumn{2}{|c|}{ Group II (Solvents) } & t & p \\
\hline PSV $(\mathrm{Cm} / \mathrm{sec})$ & $29.02 \pm$ & 10.09 & $27.10 \pm$ & 9.52 & 0.90 & 0.36 \\
\hline EDV $(\mathrm{Cm} / \mathrm{sec})$ & $3.18 \pm$ & 3.24 & $3.11 \pm$ & 3.96 & 0.86 & 0.41 \\
\hline CAD before ICI $(\mathrm{mm})$ & $0.53 \pm$ & 0.139 & $0.52 \pm$ & 0.14 & 0.31 & 0.75 \\
\hline CAD after ICI (mm) & $0.93 \pm$ & 0.13 & $0.95 \pm$ & 0.18 & 0.61 & 0.54 \\
\hline Maintenance flow & $20.36 \pm$ & 3.83 & $22.05 \pm$ & 3.73 & 2.07 & $0.041^{*}$ \\
\hline RI & $0.77 \pm$ & 0.11 & $0.78 \pm$ & 0.13 & 0.39 & 0.69 \\
\hline
\end{tabular}




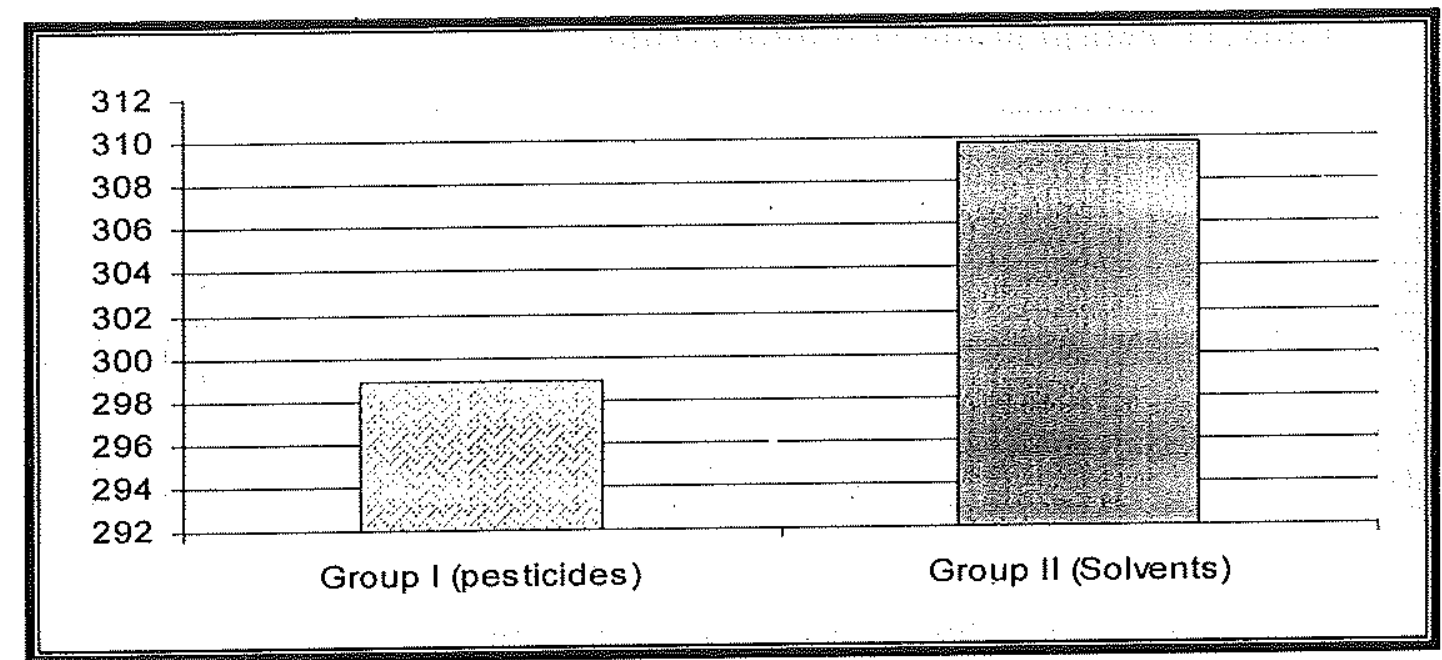

Fig. (1): Mean serum testosterone levels in studied groups.

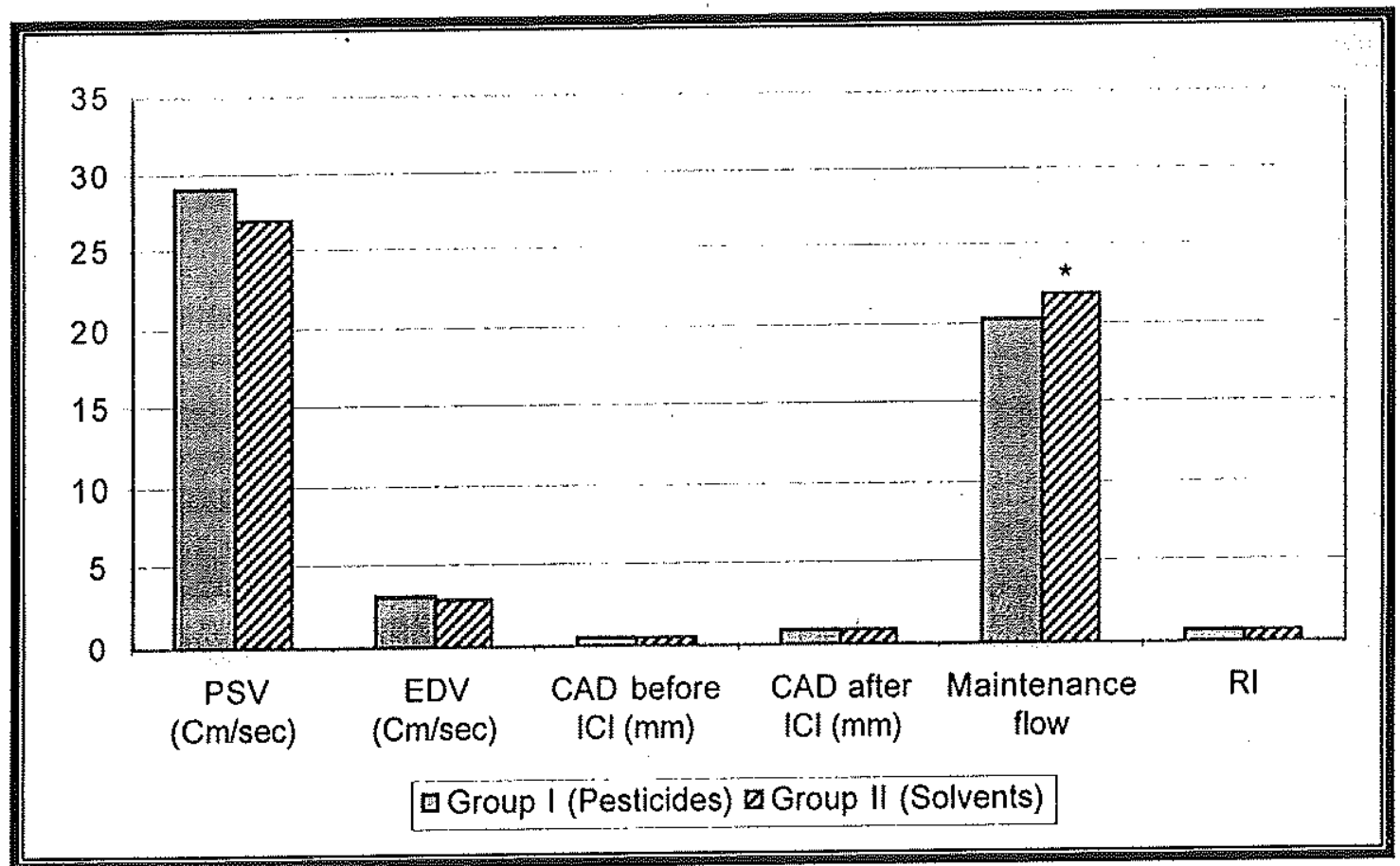

Fig. (2): Comparison between group I and II as regard radiological assessment. 


\section{REFERENCES}

Adami, H. O.; Bergstrom, R.; Mohner, 'M.; Zatonski, W.; Storm, H.; Ziegler H. and Rahu, M. (1994) : "Testicular cancer in nine northern European countries". Int. J. Cancer, 59:33-38.

Amr, M. M.; Halim, Z. S. and Moussa, S. S. (1997) : "Psychiatric disorders among Egyptian pesticide applicators". Environ. Res., 73:193-199.

Anway, M. D.; Cupp, A. S.; Uzumcu, M. and Skinner, M. K. (2005) : "Epigenetic transgenerational actions of endocrine disruptors and male fertility". Science, 308 : 1466-1469.

Bacon, C. G.; Mittleman, M. A.; Kawachi, I.; Giovanucci, E.; Glasser, D. B. and Rimm, E. B. (2003) : "Sexual function in men older than 50 years of age : results from the Health Professionals Follow-up Study". Ann. Intern. Med, 139 : 161-168.

Bennett, A. H.; Carpenter, A. J. and Barada, J. H. (1991) : "An improved vasoactive drug combination for a pharmacological erection program". J. Urol., 146 : 15641465.

Brien, S. E.; Heaton, J. P.; Racz, W. J. and Adams, M. A. (2000) : "Effects of environmental anti-androgen on erectile function in an animal penile erection mod$\mathrm{el}^{\prime \prime}$. J. Urol., 163:1315-1321.

Charlier, C. J. and Plomteux, G. J. (2002): "Determination of organochlorine pesticide residues in the blood of healthy individuals". Clin. Chem. Lab. Med., 40 : 361-364.

Christ-Crain, M.; Mueller, B.; Gasswer, T. Ci; Kraenzlin, M.; Trummler, M.; Huber, P. and Meier, C. (2004) : "Is there a clinical relevance of partial androgen deficiency of the aging male?." J. Urol., 172 : 624-627.

Dunn, K. M.; Croft, P. R. and Hackett, G. I. (1998) : "A study of the prevalence and need for health care in the general population". Fam. Pract., $15: 519-524$.

Espir, M. L.; Hall , J. W.; Shirreffs, J. G. and Stevens, D. L. (1970): "Impotence in farm workers using toxic chemicals". BMJ, 693:423-425.

Feldman, H. A.; Goldstein, I.; Krane, R. J. and McKinlay, J. B. (1994) : "Impotence and its medical and psychosocial correlates: results of the Massachusetts Male Aging Study".J. Urol., 151 : $54-61$.

Gerstenberg, T. C.; Nordling, J.; Hald, T. and Wagner, G. (1989) : "Standardized evaluation of erectile dysfunc- 
tion in 95 consecutive patients". J. Urol., 141:857-862.

Mills, T. M.; Stopper, V. S. and Reilly, C. M. (1996) : "Sites of androgenic regulation of cavernosal blood pressure during penile erection in the rat". Int. J. Impot. Res., 8:29-34.

Moreira, Jr E. D.; Abdo, C. H. N.; Torres, E. B. and Lobo, C. F. L. (2001) : "Prevalence and correlates of erectile dysfunction: results of the Brazilian study of sexual behavior". Urology, 58: 583 - 588.

Moysich, K. B.; Ambrosone, C. B.; Mendola, P.; Shields, P. G. and Freudenheim, J. L. (2002) : "Exposures associated with serum organochlorine levels among post-menopausal women from western New York State". Am. J. Indust. Med., 41:102-110.

NIH (1993) : "Consensus Development Panel on Impotence". Impotence. JAMA, 270:83-90.

Oliva, A.; Giami, A. and Multinger, L. (2002): "Environmental agents and erectile dysfunction: a study in a consulting population". J. Androl., 23:546-550.

Paris-Pombo, A. P.; Aronson, K. J.; Woolcott, C. G. and King, W. D. (2003): "Dietary predictors of breast adipose tissue concentrations of PCBs among women. in Ontario, Canada". Arch. Environ. Health, 58:48-54.

Polsky, J. Y.; Aronson, J. K.; Heaton, K. W. and Adams, M. A. (2007) : "Pesticides and polychlorinated biphenyls as potential risk factors for erectile dysfunction". J. Androl, 28:28-37.

Sharpe, R. M. and Skakkebaek, N. F. (1993) : "Are estrogens involved in falling sperm counts and disorders of the male reproductive tract?." Lancet., 341:1392-1395.

Swan, S. H.; Elkin, E. P. and Fenster, L. (2000): "The question of declining sperm density revisited: an analysis of 101 studies published 1934-1996". Environ. Health Perspect, 108:961-966.

Toppari, J.; Haavisto, A. M. and Alanen, $M$. (2002) : "Changes in male reproductive health and effects of endocrine disruptors in Scandinavian countries". Cad. Saude. Publica, 18:413-420.

Toppari, J.; Larsen, J. C.; Christiansen, P. and Giwercman, A. (1996) : "Male reproductive health and environmental xenoestrogens". Eviron. Health Perspect, 104:741-803.

Utiger, R. D. (1998) : "A pill for impotence". N. Engl. J. Med., 338:1458-1459.

Ventegodt, S. (1998) : "Sex and the 
quality of life in Denmark". Arch. Sex Behav, 27: 295 - 307.

- Vrijheid, M.; Armstrong, B.; Dolk, H.; van Tongeren, M. and Botting, B. (2003): "Risk of hypospadias in relation to maternal occupational exposure to potential endocrine disrupting chemicals". Occup. Environ. Med., 60:543-550.

Wetherill, Y. B.; Fisher, N. L.; Staubach, A.; Danielsen, M. and Knudsen, K. E. (2005) : "Xenoestrogen action in prostate cancer: pleiotropic effects dependent on androgen receptor status". Cancer Res., $65: 54-65$.

Wolff, M. S.; Camann, D.; Gammon, M. and Stellman, S. D. (1997) : "Proposed PCB congener groupings for epidemiological studies". Environ. Health Perspect, 105:13-14.

Zohdy, W.; Emad, E. K. and I., Yasser (2007) : "Androgen deficiency and abnormal penile duple parameters in obese men with erectile dysfunction". J. Sex Med., 4 : 797-808. 


\section{ضعف الإنتصاب فن العهال الذين يتعرضون - بصورة هزهنة - لهبيدات الآلات

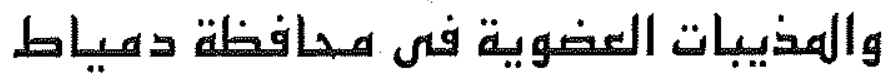

$$
\text { المشتركون فى البحث }
$$

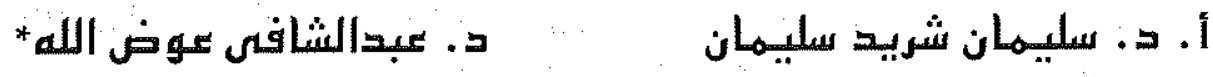

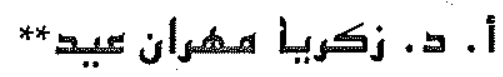

$$
\begin{aligned}
& \text { من أتسام الطب الشرعى والسمبو الإكلينيكية، والأشــة* } \\
& \text { والجلديسة والتناسـلية ** كلية طب الأزهـر - جامعــ دمبـاط }
\end{aligned}
$$

بعرن ضعف الانتصاب بأنه عدم القدرة - المستمر - لتحقيق أو المحافظة على إنتصاب كان لآداء جنسى متوازن ومنزضى. ويكن أن ترجع أسباب ضعف الانتصاب إلى أسباب نى الجهاز العصبى (المركزى أو الطرفى) ، أسباب نفسية، أسباب فى جهاز الغدد

$$
\text { الصهاء. أو أسباب موضعية ( نى تركيب العضو أو وظيفته) أر أسباب ترجع إلى المواد السامة. }
$$

رتد صمدت هذه الدراسة - كأول دراسة من نوعها فى محانظة دمباط - لاستكثان العلاذة المحتملة بين التعرض لمبيدات الآفات والمذيبات

$$
\text { العضوية بصورة هزمنة وبين ضعف الانتصاب والآلية المحتفلة فى حدوث هذه المئكلة. }
$$

رتد أجريت الدراسة فى الفترة من أبريل 2006 إلى أبريل 2008، وشملت 87 مريضا من تحققت فيهم شروط الاشتمال فى البحث، وفى نفس

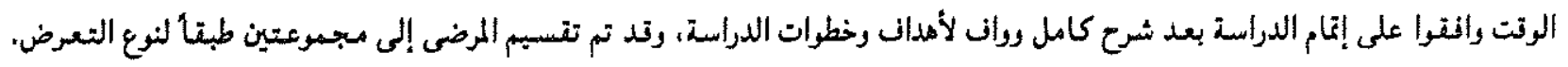

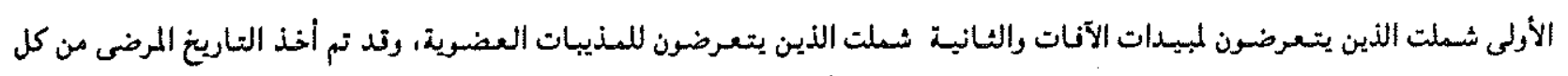
المشاركين، وتم نحصهم إكلينيكياً ثم الفحص المعملى لكمية الهرمون الذكرى (التستوستيرون) نى الدم، وأخبرا الفحص الإشعاعى، حيث تم عمل دويلكس على العضو الذكرى.

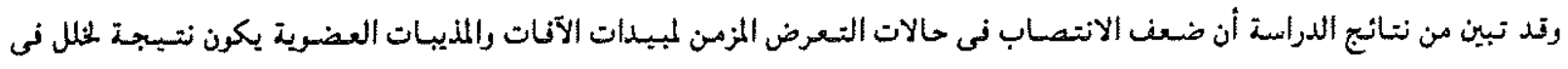
ميكانيكية غلق الأرعية الدموية فى العضو الذكرى، ويشارل نى حدوث هذا المللل أكثر من عامل، ويحتاج الموضوع لبحوث أخرى لتغطبة كافة جوانبه المحتملة. 